Article

\title{
Numerical Study of (Au-Cu)/Water and (Au-Cu)/Ethylene Glycol Hybrid Nanofluids Flow and Heat Transfer over a Stretching Porous Plate
}

\author{
Umair Rashid ${ }^{1}$, Azhar Iqbal ${ }^{2, *}$ and Abdullah Alsharif ${ }^{3}$ \\ 1 CAS Key Laboratory of Mechanical Behavior and Design of Materials, Department of Modern Mechanics, \\ University of Science and Technology of China, Hefei 230026, China; umair2014@mail.ustc.edu.cn \\ 2 Department of Mathematics and Natural Sciences, Prince Mohammad Bin Fahd University, \\ Al Khobar 31952, Saudi Arabia \\ 3 Department of Mathematics and Statistics, College of Science, Taif University, P.O. Box 11099, \\ Taif 21944, Saudi Arabia; a.alshrif@tu.edu.sa \\ * Correspondence: aiqbal@pmu.edu.sa
}

check for updates

Citation: Rashid, U.; Iqbal, A.; Alsharif, A. Numerical Study of $(\mathrm{Au}-\mathrm{Cu}) /$ Water and $(\mathrm{Au}-\mathrm{Cu}) /$ Ethylene Glycol Hybrid Nanofluids Flow and Heat Transfer over a Stretching Porous Plate. Energies 2021, 14, 8341. https://doi.org/ 10.3390/en14248341

Academic Editors: Zafar Said and Evangelos Bellos

Received: 2 November 2021

Accepted: 9 December 2021

Published: 10 December 2021

Publisher's Note: MDPI stays neutral with regard to jurisdictional claims in published maps and institutional affiliations.

Copyright: (c) 2021 by the authors. Licensee MDPI, Basel, Switzerland. This article is an open access article distributed under the terms and conditions of the Creative Commons Attribution (CC BY) license (https:// creativecommons.org/licenses/by/ $4.0 /)$.

\begin{abstract}
The purpose of the study is to investigate the (Au-Cu)/Water and (Au-Cu)/Ethylene glycol hybrid nanofluids flow and heat transfer through a linear stretching porous plate with the effects of thermal radiation, ohmic heating, and viscous dissipation. Similarity transformations technique is used to transform a governing system of partial differential equations into ordinary differential equations. The NDSolve Mathematica program is used to solve the nonlinear ordinary differential equations. Furthermore, the results are compared with the results of homotopy analysis method. The impacts of relevant physical parameters on velocity, temperature, and the Nusselt number are represented in graphical form. The key points indicate that the temperature of $(\mathrm{Au}-\mathrm{Cu}) / \mathrm{water}$ and $(\mathrm{Au}-\mathrm{Cu}) /$ Ethylene glycol hybrid nanofluids is increased with the effects of Eckert number and magnetic field. The (Au-Cu)/Ethylene glycol hybrid nanofluid also has a greater rate of heat transfer than $(\mathrm{Au}-\mathrm{Cu}) /$ Water hybrid nanofluid.
\end{abstract}

Keywords: thermal radiation; partial differential equation; hybrid nanofluid; porous medium

\section{Introduction}

The NDSolve (wolfram language) function is a general numerical differential equation solver. The NDSolve can handle a wide range of partial differential equations as well as ordinary differential equations. The NDSolve can be used to find the unknown functions that must depend on a single variable. The differential-algebraic equation can be solved by the NDSolve technique. Several significant studies are presented by using the NDSolve technique. Hayat et al. [1] examined the numerical solution of Darcy Forchheimer's nanofluid flow over-stretching curved surface via the NDSolve Mathematica technique.

Ullah et al. [2] used differential transform method, Adomian decomposition method, Daftardar-Jafari method, optimal homotopy asymptotic method, homotopy perturbation method, and the NDSolve Mathematica program to examine the magnetohydrodynamic squeezing flow of viscous fluid with slip effect. Ahmad et al. [3] analyzed the unsteady squeezing flow and entropy generation of viscous $\mathrm{Al}_{2} \mathrm{O}_{3}$-water, $\mathrm{TiO}_{2}$-water, $\mathrm{CuO}$-water, $\mathrm{Ag}$-water, and $\mathrm{Cu}$-water nanofluids with the help of the NDSolve Mathematica technique. The effects of magnet field, thermal radiation, Joule heating, and viscous dissipation are also studied. Qayyum et al. [4] used the NDSolve Mathematica technique to discuss the theoretical investigation and modeling of curved parabolized surface with secondorder slip condition. Li et al. [5] explored the entropy optimized viscous fluid with the help of Newton's built-in work on 3D boundary layer flow of a DO- $\left(\mathrm{TiO}_{2} / \mathrm{SiC}\right)$ hybrid nanofluid shooting technique (NDSolve). Silent features entropy generation, Bejan number, concentration, velocity, and temperature are deliberated. 
Many researchers conducted work on nanofluids, for example, Kristiawan et al. [6] dicussed numerical solution of the $\mathrm{TiO}_{2} / \mathrm{H}_{2} \mathrm{O}$ nanofluid flow with heated uniform boundary conditions. Kristianwan et al. [7] experimently examined the $\mathrm{TiO}_{2} / \mathrm{H}_{2} \mathrm{O}$ nanofluid flow in a helical microfin tube. Currently, a novel approach known as hybrid nanofluid is used for heat transfer in fluids. Researchers are interested in hybrid nanofluid because of its numerous industrial, scientific, and technical applications, including microfluidics, generator cooling, transportation, manufacturing, pharmaceutical lubricating, acoustics, naval structures, and solar energy, among others. Choi [8] introduced the concept of nanofluid, which was a game-changer. The term "hybrid" refers to a homogeneous phase made up of two or more nanoparticles with chemical and physical properties that differ from one another [9]. The effect of nanoparticle temperature and concentration distribution on the rheology behavior of ethylene glycol- $\left(\mathrm{Fe}_{3} \mathrm{O}_{4} / \mathrm{Ag}\right)$ hybrid nanofluid was investigated by Afrand et al. [10]. Mehrali et al. [11] used tannic acid, graphene oxide, and iron salts to create a reduced $\left(\mathrm{Fe}_{3} \mathrm{O}_{4}\right.$ /graphene oxide) hybrid nanofluid for stabilization and redundancy. The use of hybrid nanofluid has been shown to enhance thermal conductivity. Anuar et al. [12] discussed the Water- $\left(\mathrm{Al}_{2} \mathrm{O}_{3} / \mathrm{Cu}\right)$ hybrid nanofluid stagnation point flow over the shrinking/stretching sheet with the presence of heterogeneous and homogeneous reactions. Kashi et al. [13] studied hybrid boundary layer flow due to cylinder and flat plate with prescribed surface heat flux. Khan et al. [14] worked on chemically reactive and bioconvective hybrid nanofluid flow upon a horizontally moving needle. Sulochana and Kumar [15] presented the Water- $\left(\mathrm{Fe}_{3} \mathrm{O}_{4} / \mathrm{Ag}\right)$ hybrid nanofluid flow across a nonlinear stretching surface while considering the effects of viscous dissipation and thermal radiation. Sulochana and Kumar found that physical parameters known as thermophoresis, radiation, and Brownian motion increase temperature profile. This increase is more significant for $\left(\mathrm{Fe}_{3} \mathrm{O}_{4} / \mathrm{Ag}\right)$ hybrid nanofluid than the mono particle nanofluid. Mdallal et al. [16] observed the effects of Marangoni radiative on $\left(\mathrm{Al}_{2} \mathrm{O}_{3} / \mathrm{SiO}_{2}\right)$-water, $\left(\mathrm{Al}_{2} \mathrm{O}_{3} / \mathrm{TiO}_{2}\right)$-water, and $\left(\mathrm{TiO}_{2} / \mathrm{SiO}_{2}\right)$-water hybrid nanofluid flow over a permeable surface in the presence of the magnetic field. Waini et al. [17] investigated the numerical results of the Water- $\left(\mathrm{Al}_{2} \mathrm{O}_{3} / \mathrm{Cu}\right)$ hybrid nanofluid stagnation point flow over the shrinking/stretching cylinder. Zainal et al. [18] used the Bvp4c Matlab function to discuss the stability analysis of magnetohydrodynamic Water- $\left(\mathrm{Al}_{2} \mathrm{O}_{3} / \mathrm{Cu}\right)$ hybrid nanofluid flow along with a shrinking/stretching sheet. Babazadeh et al. [19] studied the finite element method to explore the hybrid nanofluid analysis within a porous medium in the presence of thermal radiation and Lorentz forces.

Porous medium transport phenomena have received a lot of attention due to their usefulness in a wide range of industrial and engineering applications. Moreover, significant growths produced biomedical applications using a porous medium, such as tissue replacement, enhanced medical imaging, medication administration, transportation in biological tissues, and porous artificial implants. Many researchers recently used the extended model to examine investigations in porous media [20-22]. Masood et al. [23] presented the viscous nanofluid flow past a stretching/shrinking sheet with the effect of thermophoresis, Brownian motion, and magnetic Reynolds number. Alaidrous and Eid [24] examined the magnetic flow of non-Newtonian nanofluid with the impacts of several slips, viscous dissipation, joule heating, and thermal radiation. Akbar et al. [25] investigated the approximate solution of mass and heat transfer of viscous magnetohydrodynamic (MHD) nanofluid through a channel in a porous medium. Mishra and Mathur [26] examined the Williamson nanofluid flow through porous medium with the effect of Brownian motion, thermophoresis, chemical reaction, and thermal radiation. Uddin et al. [27] analyzed the numerical solution of the non-Newtonian convection nanofluid flow over a horizontal flat plate through a porous medium in the presence of gyrotactic microorganisms. They found that for increasing the value of porosity, source (sink) and radiation parameter, the heat transfer rate was diminished. Lund et al. [28] investigated magnetized Water$\left(\mathrm{Al}_{2} \mathrm{O}_{3} / \mathrm{Cu}\right)$ hybrid nanofluid flow and heat transfer along with a stretching sheet with the presence of magnetohydrodynamic (MHD), porous medium, and viscous dissipation. Ting et al. [29] discussed the flow and heat characteristics of Water- $\mathrm{Al}_{2} \mathrm{O}_{3}$ nanofluid in a porous 
microchannel. Beg et al. [30] developed the mathematical model of steady-state mixed bio-convection nanofluid flow over a vertical wall and found the approximate solution of the proposed model.

The literature mentioned above observed that several researchers worked on hybrid nanofluid flow and porous medium. The goal of this research is to examine the numerical results of $(\mathrm{Au}-\mathrm{Cu}) /$ Water and $(\mathrm{Au}-\mathrm{Cu}) /$ Ethylene glycol hybrid nanofluids flow and heat transfer over a stretching porous plate. The effects of physical parameters are explained in graphical form.

\section{Problem Formulations}

The 2-D incompressible hybrid nanofluids over a linear stretching porous plate are considered. A uniform magnetic field parallel to the y-axis is applied. The electric field and magnetic field B are assumed to be negligible. It is also assumed that the flow influences thermal radiation, viscous dissipation, and ohmic heating. The nanoparticles and fluid are in equilibrium and no-slip occurs between them. The geometry of the problem is displayed as [31] (Figure 1).

$$
\begin{gathered}
\frac{\partial u}{\partial x}+\frac{\partial v}{\partial y}=0 \\
\left(u \frac{\partial u}{\partial x}+v \frac{\partial u}{\partial y}\right)=\frac{u_{h n_{f}}}{\rho_{h n f}} \frac{\partial^{2} u}{\partial y^{2}}-\frac{\sigma_{h n_{f}} B^{2}}{\rho_{h n f}} u-\frac{u_{h n_{f}}}{\rho_{h n f}} \frac{\epsilon}{K 1} u \\
u \frac{\partial T}{\partial x}+v \frac{\partial T}{\partial y}=\alpha_{n_{f}} \frac{\partial^{2} T}{\partial y^{2}}-\frac{1}{(\rho C p)_{h n f}}\left[u_{h n_{f}}\left(\frac{\partial u}{\partial y}\right)^{2}-\frac{\partial q_{r}}{\partial y}+\sigma B^{2} u^{2}\right], \\
u=c x, v=-v_{0}, T=T_{w} \text { at } y=0, \\
u \rightarrow 0, T \rightarrow T_{\infty} \text { as } y \rightarrow \infty .
\end{gathered}
$$

Here, $u, v, T, T_{w}$, and $T_{\infty}$ are velocities, the temperature of hybrid nanofluid, wall temperature, and far field temperature, respectively. $B, \sigma$, and $q_{r}$ are the magnetic field, electrical conductivity, and radiative heat flux, respectively.

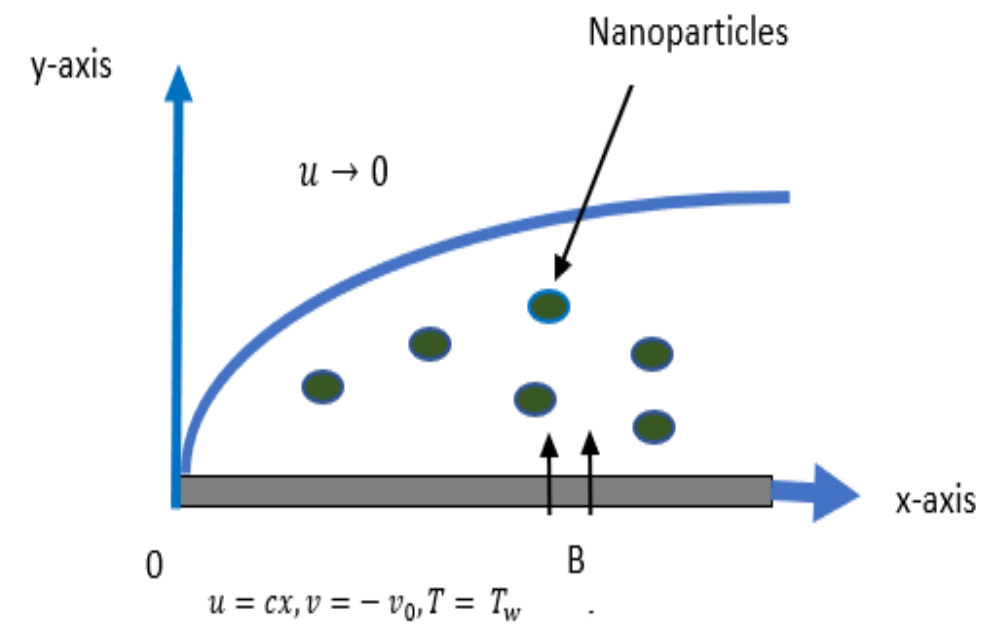

Figure 1. The geometry of the problem.

The radiative heat flux is transformed into the following form using the Rosseland approximation:

$$
q_{r}=-\frac{\sigma^{*}}{3 k^{*}} \cdot \frac{\partial T^{4}}{\partial y}
$$

where $k^{*}$ is the mean absorption and $\delta^{*}$ is the Stefan-Boltzmann. Moreover, the temperature within the flow was expected to be low, thus $T^{4}$ was stated as a linear function of 
temperature. As a result of applying the Taylor series and ignoring higher-order terms, $T^{4}$ is obtained as:

$$
T^{4} \approx 4 T_{\infty}^{3} T-3 T_{\infty}^{4}
$$

The similarity transformations are:

$$
u=c x f^{\prime}(\eta), v=-\sqrt{v c} f(\eta), \eta=y \sqrt{\frac{c}{v}}, \theta(\eta)=\frac{T-T_{\infty}}{T_{w}-T_{\infty}} .
$$

By using Equations (4)-(7), Equations (1)-(3) become:

$$
\begin{gathered}
f^{\prime \prime \prime}+A_{1} f f^{\prime \prime}-A_{1} f^{2}-A_{2} f^{\prime}=0, \\
\theta^{\prime \prime}+A_{3} \operatorname{Pr} f \theta^{\prime}+E c P r A_{5} f^{\prime \prime 2}+M E c \operatorname{Pr} A_{6} f^{\prime 2}=0 \\
A 1=\left[\left(1-\phi_{2}\right)\left\{\frac{\left(1-\phi_{1}\right) \rho_{f}+\left(1-\phi_{2}\right) \rho_{s 1}}{\rho_{f}}\right\}+\phi_{2} \rho_{s 1}\right]\left(1-\phi_{1}\right)^{2 \times 5}\left(1-\phi_{2}\right)^{2 \times 5}, \\
A_{2=\frac{1}{k}}+M *\left(1-\phi_{1}\right)^{2 \times 5}\left(1-\phi_{2}\right)^{2 \times 5}, \\
A_{3=} \frac{\left(1-\phi_{2}\right)\left\{\left(1-\phi_{1}\right)(\rho C p)_{f}+\phi_{1}(\rho C p)_{s 1}\right\}+\phi_{2}(\rho C p)_{s 2}}{(\rho C p)_{f}} \frac{1}{A_{4}} \frac{1}{\omega *\left(1-\phi_{1}\right)^{2 \times 5}\left(1-\phi_{2}\right)^{2 \times 5}} \\
A_{4}=\frac{\left[k_{s 2}+(m-1) k b_{f}\right]-(m-1) \phi_{2}\left(k_{b f}-k_{s 2}\right)}{\left[k_{s 2}+(m-1) k b_{f}\right]+\phi_{2}\left(k b_{f}-k_{s 2}\right)}, \\
\text { where } \frac{k_{b f}}{k_{f}}=\frac{\left[k_{s 1}+(m-1) k_{f}\right]-(m-1) \phi_{1}\left(k_{f}-k_{s 1}\right)}{\left[k_{s 1}+(m-1) k_{f}\right]+\phi_{1}\left(k_{f}-k_{s 1}\right)} . \\
A_{5}=\frac{1}{A_{4}} \frac{1}{\omega *\left(1-\phi_{1}\right)^{2 \times 5}\left(1-\phi_{2}\right)^{2 \times 5},} \\
A_{6}=\frac{1}{\omega * A_{4}}, \text { and } \omega=1+\frac{4}{3 * R} .
\end{gathered}
$$

The relevant boundary conditions are described as a fellow:

$$
f(0)=m, f^{\prime}(0)=1, f^{\prime}(\infty)=0, \theta(0)=1, \theta(\infty)=0,
$$

where $R$ represents the radiation parameter, $m$ is the injection parameter, $\operatorname{Pr}$ denotes the Prandtl number, $E c$, represents the Eckert number, $k$ represents the porous medium, and $M$ represents the magnetic parameter. Table 1 displays the thermophysical characteristics of water and nanoparticles.

Table 1. Thermo-physical characteristics of water and nanoparticles.

\begin{tabular}{ccccc}
\hline Physical Properties & $\mathbf{A u}$ & $\mathbf{C u}$ & Pure Water & Ethylene Glycol \\
\hline$C p(\mathrm{~J} / \mathrm{kg} \mathrm{K})$ & 129 & 385 & 4179 & 2430 \\
$\rho\left(\mathrm{kg} / \mathrm{m}^{3}\right)$ & 19,300 & 8933 & 997.1 & 1115 \\
$k(\mathrm{~W} / \mathrm{m} \mathrm{K})$ & 318 & 400 & 0.613 & 0.253 \\
\hline
\end{tabular}

The local Nusselt number $(\mathrm{N} u)$ is given as:

$$
N u=\frac{x q_{w}(x)}{k_{f}\left[T_{w}-T_{\infty}\right]},
$$

where, $q_{w}(x)=-k_{n_{f}}\left(\frac{\partial T}{\partial y}\right)_{y=o}$.

\section{Results and Discussion}

The effects of different physical parameters such as radiation, injection, Prandtl number, Eckert number, and magnetic parameter on velocity and temperature profiles are investigated. The heat transfer rate is also represented graphically. Figure 2 shows that 
the velocity of $(\mathrm{Au}-\mathrm{Cu}) /$ Water hybrid nanofluid is greater than $(\mathrm{Au}-\mathrm{Cu}) /$ Ethylene glycol hybrid nanofluid. Figure 3 explains the velocity distribution of $(\mathrm{Au}-\mathrm{Cu}) /$ Water and $(\mathrm{Au}-$ $\mathrm{Cu}$ )/Ethylene glycol hybrid nanofluids for the dissimilar value of $\phi_{1}$ and $\phi_{2}$. It is noted from Figure 3 that the velocity of $(\mathrm{Au}-\mathrm{Cu}) /$ Water and $(\mathrm{Au}-\mathrm{Cu}) /$ Ethylene glycol hybrid nanofluids decrease with the increase of $\phi_{1}$ and $\phi_{2}$. This occured because the $\mathrm{Au}$ and $\mathrm{Cu}$ nanoparticles possess higher thermal conductivity than the water and Ethylene glycol. The velocity of $(\mathrm{Au}-\mathrm{Cu}) /$ Water and $(\mathrm{Au}-\mathrm{Cu}) /$ Ethylene glycol hybrid nanofluids within the influences of $M$ is displayed in Figure 4. As seen in Figure 4, the velocity of $(\mathrm{Au}-\mathrm{Cu}) /$ Water and $(\mathrm{Au}-\mathrm{Cu}) /$ Ethylene glycol hybrid nanofluids have an inverse relation with $M$. Physically, the Lorentz force generated by $M$ acted against the motion of $(\mathrm{Au}-\mathrm{Cu}) /$ Water and $(\mathrm{Au}-\mathrm{Cu}) /$ Ethylene glycol hybrid nanofluids. The velocity of $(\mathrm{Au}-\mathrm{Cu}) /$ Water and $(\mathrm{Au}-$ $\mathrm{Cu}$ )/Ethylene glycol hybrid nanofluids flow with a variation of $m$, as shown in Figure 5. It is noted from Figure 5 that the velocity of $(\mathrm{Au}-\mathrm{Cu}) /$ Water and $(\mathrm{Au}-\mathrm{Cu}) /$ Ethylene glycol hybrid nanofluids decrease with the enhancement of $m$. This is due to the removal of nanofluid particles through porous surface that reduced the boundary layer thickness. Figure 6 shows the velocity of $(\mathrm{Au}-\mathrm{Cu}) /$ Water and $(\mathrm{Au}-\mathrm{Cu}) /$ Ethylene glycol hybrid nanofluids for various values of $K$. As seen in Figure 4, velocity of $(\mathrm{Au}-\mathrm{Cu}) /$ Water and $(\mathrm{Au}-\mathrm{Cu}) /$ Ethylene glycol hybrid nanofluids have a direct relation with $K$. Physically porous medium reduces the resistance to hybrid nanofluids and thus enhances the velocity of $(\mathrm{Au}-\mathrm{Cu}) /$ Water and $(\mathrm{Au}-\mathrm{Cu}) /$ Ethylene glycol hybrid nanofluids. Figure 7 shows that the temperature of (Au$\mathrm{Cu}) /$ Water hybrid nanofluid is greater than $(\mathrm{Au}-\mathrm{Cu}) /$ Ethylene glycol hybrid nanofluid. This is due to the thermal conductivity of $(\mathrm{Au}-\mathrm{Cu}) /$ Water hybrid nanofluid, which is more than $(\mathrm{Au}-\mathrm{Cu}) /$ Ethylene glycol hybrid nanofluid. Figure 8 shows the effects of $\phi_{1}$ and $\phi_{2}$ on temperature distribution of $(\mathrm{Au}-\mathrm{Cu}) /$ Water and $(\mathrm{Au}-\mathrm{Cu}) /$ Ethylene glycol hybrid nanofluids. The temperature of $(\mathrm{Au}-\mathrm{Cu}) /$ Water and $(\mathrm{Au}-\mathrm{Cu}) /$ Ethylene glycol hybrid nanofluids is the inverse function of $\phi_{1}$ and $\phi_{2}$. The reason for this is that temperature distribution is eventually slowed from stretching porous plates. Figure 9 shows the temperature of $(\mathrm{Au}-\mathrm{Cu}) /$ Water and $(\mathrm{Au}-\mathrm{Cu}) /$ Ethylene glycol hybrid nanofluids with the influences of $M$. It was observed that the temperature of $(\mathrm{Au}-\mathrm{Cu}) /$ Water and $(\mathrm{Au}-\mathrm{Cu}) /$ Ethylene glycol hybrid nanofluids flow enhances with increasing the numerical value of $M$. Physically, the Lorentz force heating in the temperature equation serves as an extra heat source to the thermal boundary layer. Figure 10 depicts the impact of $\mathrm{m}$ on the temperature of $(\mathrm{Au}-\mathrm{Cu}) /$ Water and $(\mathrm{Au}-\mathrm{Cu}) /$ Ethylene glycol hybrid nanofluids. Figure 10 indicates that as $\mathrm{m}$ is increased, the temperature of the $(\mathrm{Au}-\mathrm{Cu}) /$ Water and $(\mathrm{Au}-\mathrm{Cu}) /$ Ethylene hybrid nanofluids decreases. The reason for this is that the fluid density of fluid decreases when increasing the numerical value of $\mathrm{m}$, which results in the temperature of hybrid nanofluids decreasing. Figure 11 illustrates the temperature of $(\mathrm{Au}-\mathrm{Cu}) /$ Water and $(\mathrm{Au}-\mathrm{Cu}) /$ Ethylene glycol hybrid nanofluids for dissimilar values of $R$. The temperature profiles of the hybrid nanofluids are seen to decrease as $R$ values are increased. As $T_{\infty}$ reduces as $R$ decreases, the Rosseland radiation absorptivity drops, and the thickness of the thermal boundary layer decreases. Figure 12 presents the temperature of $(\mathrm{Au}-\mathrm{Cu}) /$ Water and $(\mathrm{Au}-\mathrm{Cu}) /$ Ethylene glycol hybrid nanofluids boosted with the impacts of Ec. Physically, the fraction of heat is shown to be deposited in hybrid nanofluids. The rate of heat transfer in ( $\mathrm{Au}-\mathrm{Cu}) /$ Water and $(\mathrm{Au}-\mathrm{Cu}) /$ Ethylene glycol hybrid nanofluids is plotted in Figures 13 and 14. It is noted that in the case $(\mathrm{Au}-\mathrm{Cu}) /$ Water hybrid nanofluid the heat transfer rate has a direct and inverse relationship with $R$ and $m$, respectively. In case of (Au-Cu)/Ethylene glycol hybrid the rate of heat transfer has a direct relationship with $R$ and $m$. The heat transfer rate of $(\mathrm{Au}-\mathrm{Cu})$ /Ethylene glycol hybrid nanofluids is higher than the heat transfer rate of $(\mathrm{Au}-\mathrm{Cu}) /$ Water hybrid nanofluids. To check the accuracy of numerical solution, the results obtained by the NDSolve method are compared with the homotopy analysis method. Figures 15 and 16 are presented as a comparison of the velocity and temperature of (Au$\mathrm{Cu}$ /Ethylene glycol hybrid nanofluid. Figure 17 presents the error decay for 10th-order approximation. Tables 2 and 3 show an excellent comparison of velocity and temperature profiles of $(\mathrm{Au}-\mathrm{Cu}) /$ Ethylene hybrid nanofluid. To ensure the validity of our findings, 
we compared the results of our study $($ for $\theta \prime(0))$ with the published results of Chen [32], Zaimi et al. [33], and Naramgari and Sulochana [34] for $m=0, E c=0, M=0, \phi_{1}, \phi_{2}=0$ as shown in Table 4 . The obtained results are found in good agreement with the published results.

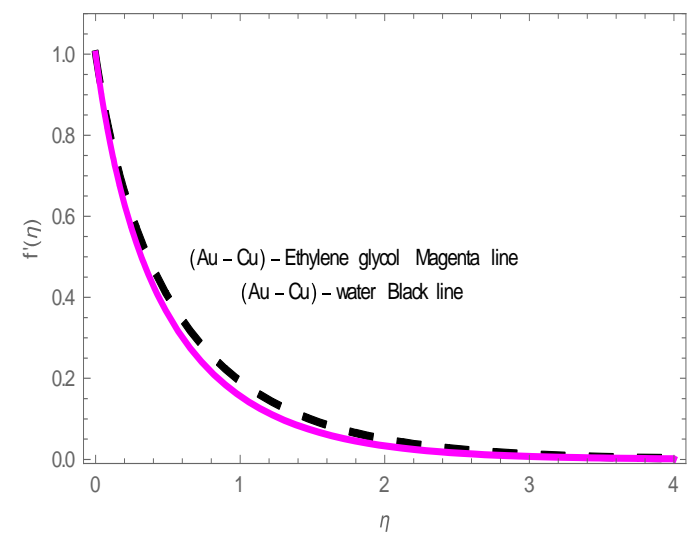

Figure 2. $f^{\prime}(\eta)$ for $(\mathrm{Au}-\mathrm{Cu}) /$ Water and $(\mathrm{Au}-\mathrm{Cu}) /$ Ethylene hybrid nanofluids.

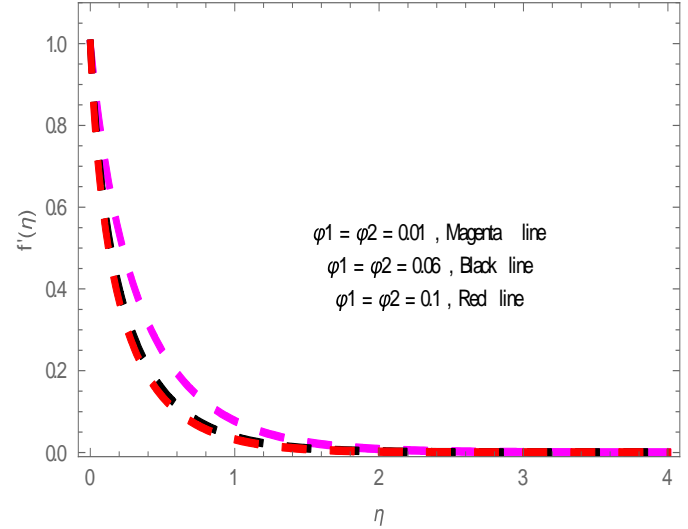

(a) $(\mathrm{Au}-\mathrm{Cu}) /$ Water hybrid nanofluids.

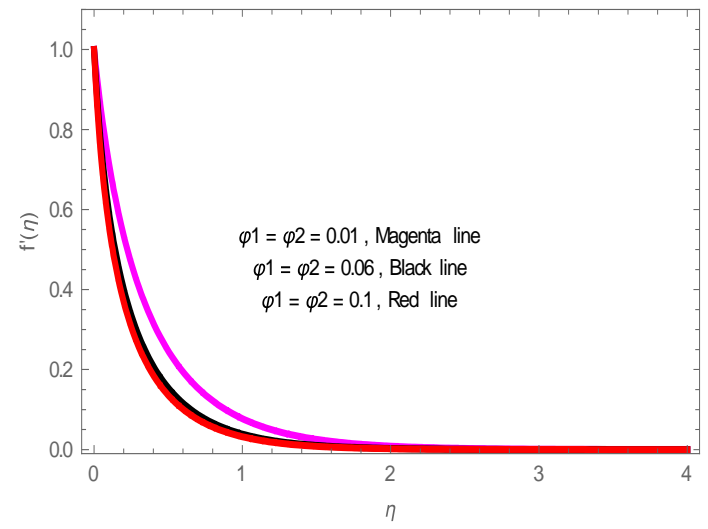

(b) $(\mathrm{Au}-\mathrm{Cu}) /$ Ethylene hybrid nanofluids.

Figure 3. $f^{\prime}(\eta)$ for dissimilar values of $\phi_{1}$ and $\phi_{2}$.

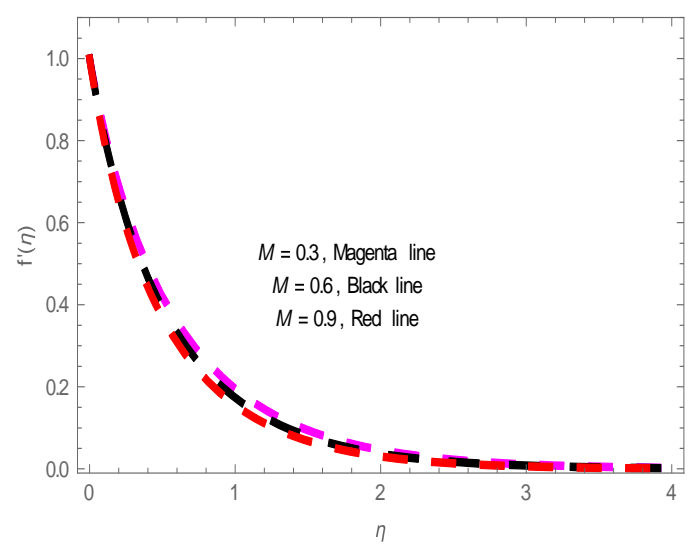

(a) $(\mathrm{Au}-\mathrm{Cu}) /$ Water hybrid nanofluids.

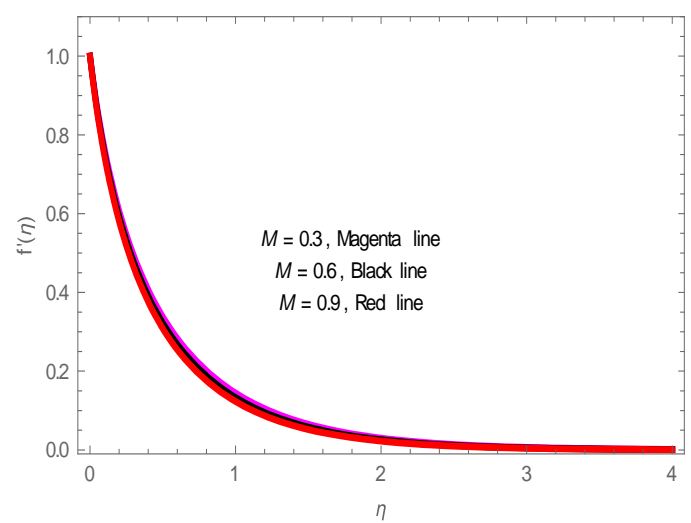

(b) $(\mathrm{Au}-\mathrm{Cu}) /$ Ethylene hybrid nanofluids.

Figure 4. $f^{\prime}(\eta)$ for dissimilar values of $M$. 


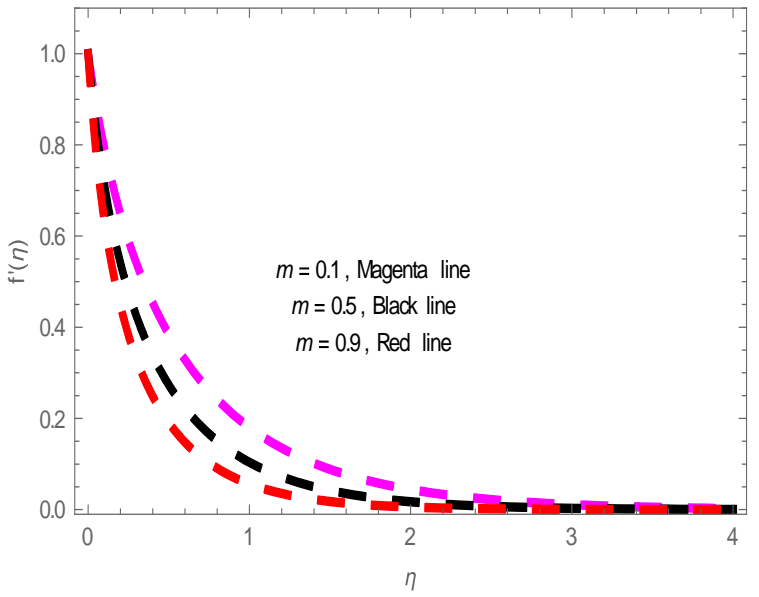

(a) $(\mathrm{Au}-\mathrm{Cu}) /$ Water hybrid nanofluids.

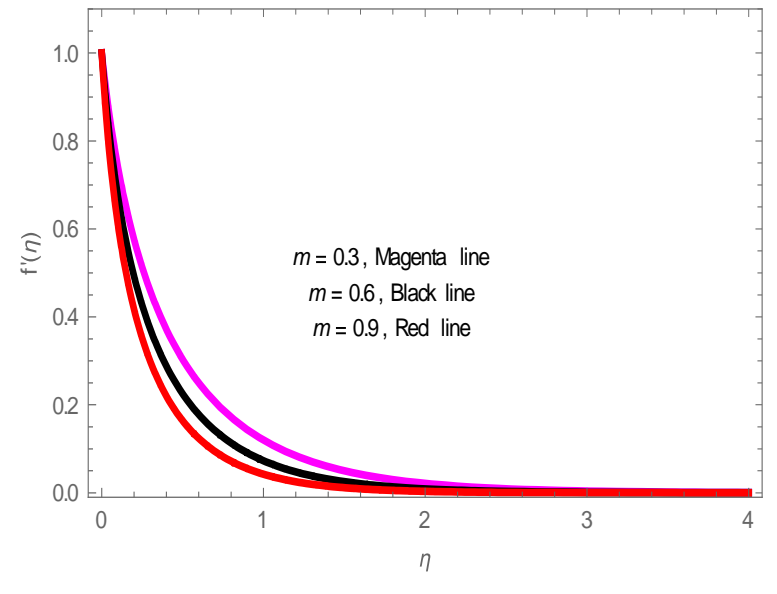

(b) (Au-Cu)/Ethylene hybrid nanofluids.

Figure 5. $f^{\prime}(\eta)$ for dissimilar values of $m$.

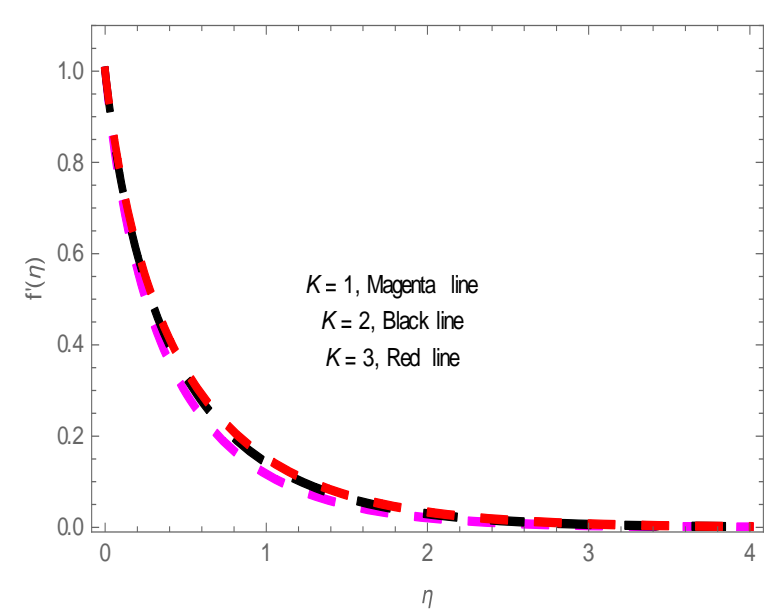

(a) $(\mathrm{Au}-\mathrm{Cu}) /$ Water hybrid nanofluids.

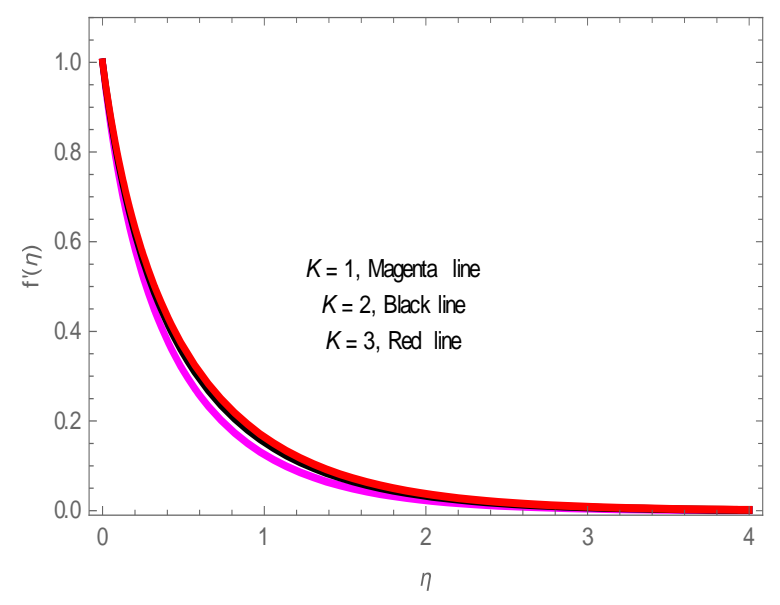

(b) (Au-Cu)/ Ethylene hybrid nanofluids.

Figure 6. $f^{\prime}(\eta)$ for dissimilar values of $K$.

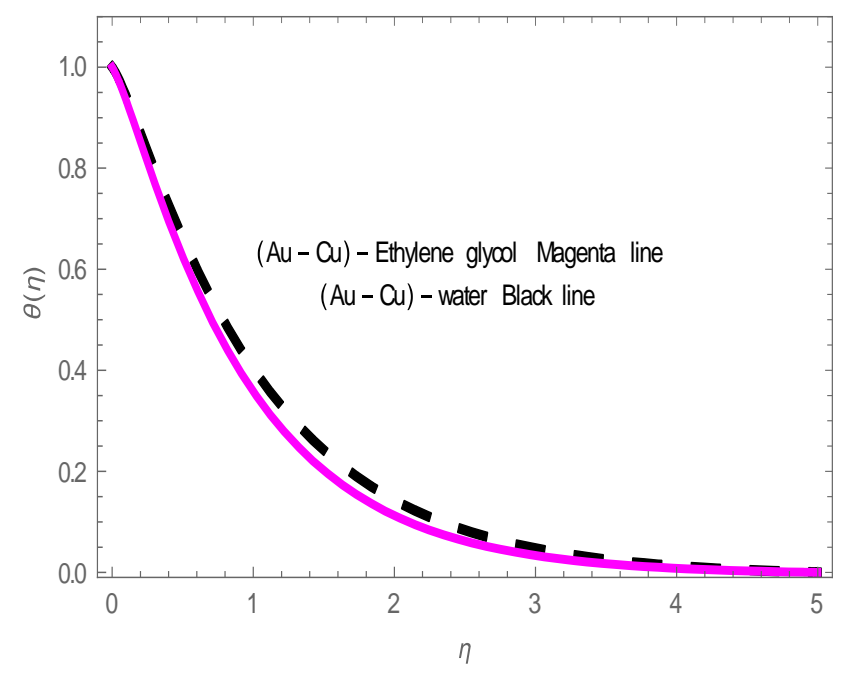

Figure 7. $\theta(\eta)$ for $(\mathrm{Au}-\mathrm{Cu}) /$ Water and $(\mathrm{Au}-\mathrm{Cu}) /$ Ethylene hybrid nanofluids. 


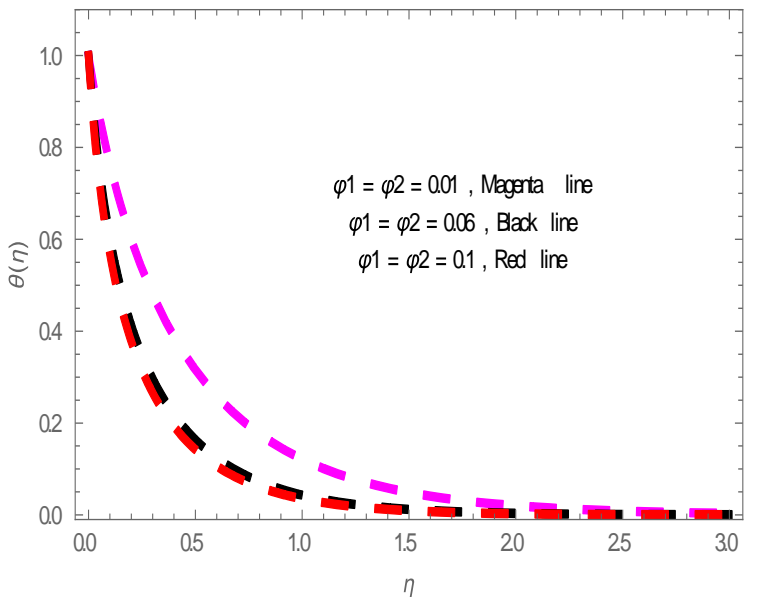

(a) $(\mathrm{Au}-\mathrm{Cu}) /$ Water hybrid nanofluids.

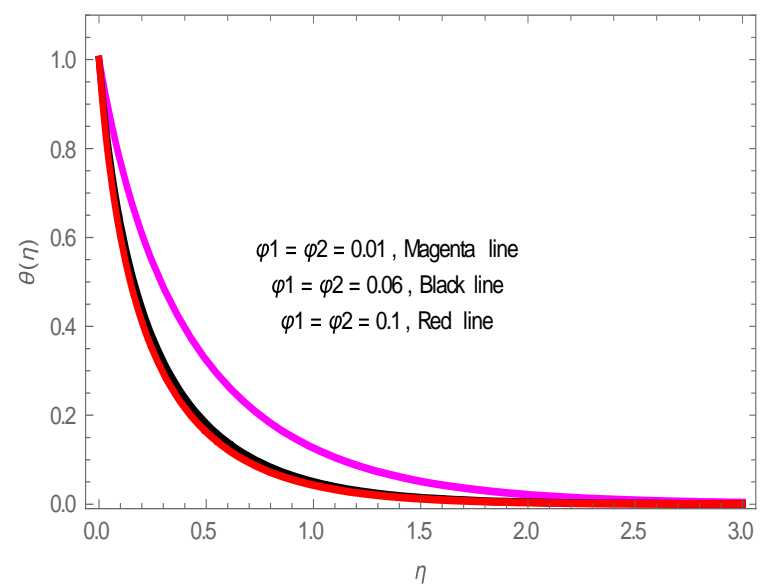

(b) (Au-Cu)/Ethylene hybrid nanofluids.

Figure 8. $\theta(\eta)$ for dissimilar values of $\phi_{1}$ and $\phi_{2}$.
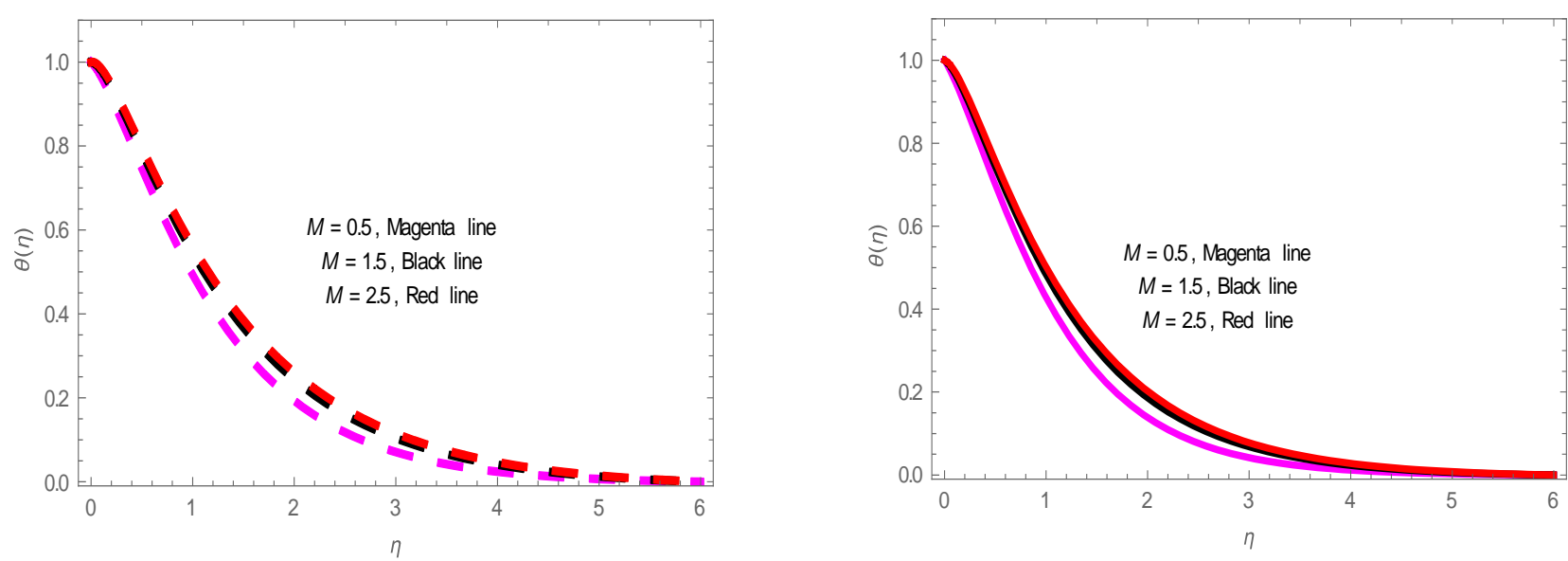

Figure 9. $\theta(\eta)$ for dissimilar values of $M$.

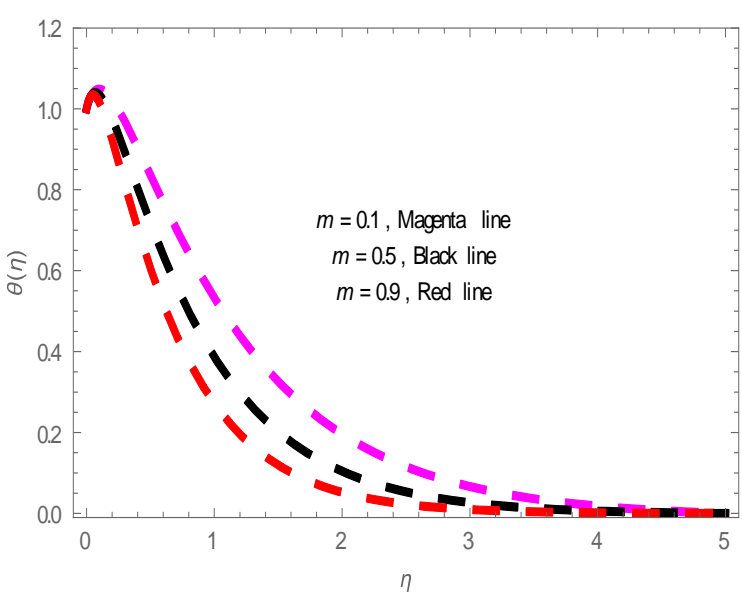

(a) (Au-Cu)/Water hybrid nanofluids.

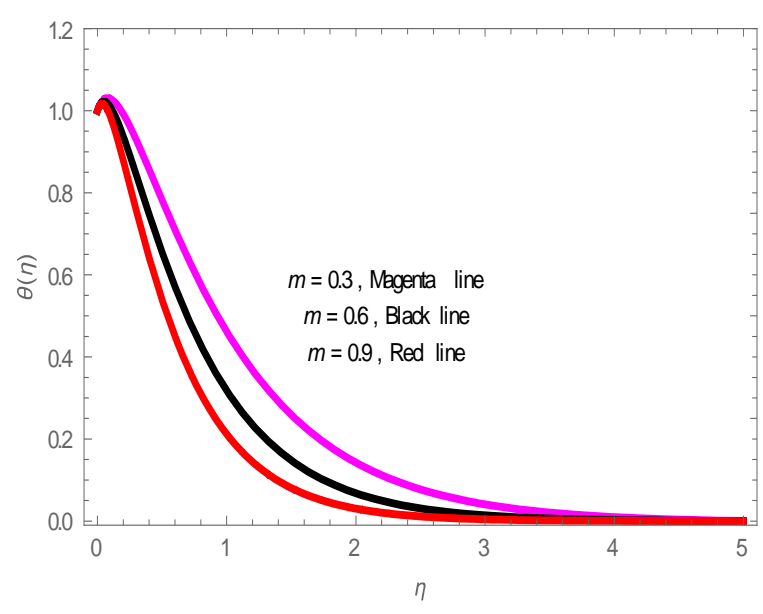

(b) $(\mathrm{Au}-\mathrm{Cu}) /$ Ethylene hybrid nanofluids.

Figure 10. $\theta(\eta)$ for dissimilar values of $m$. 


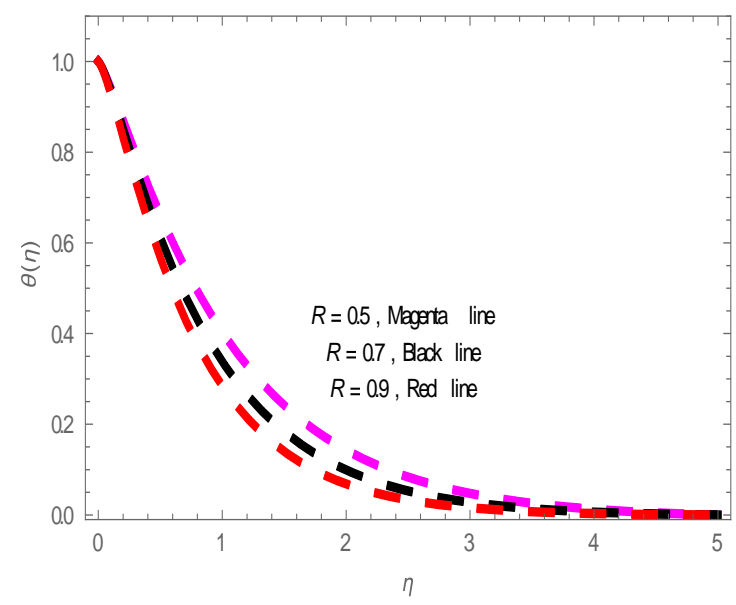

(a) $(\mathrm{Au}-\mathrm{Cu}) /$ Water hybrid nanofluids.

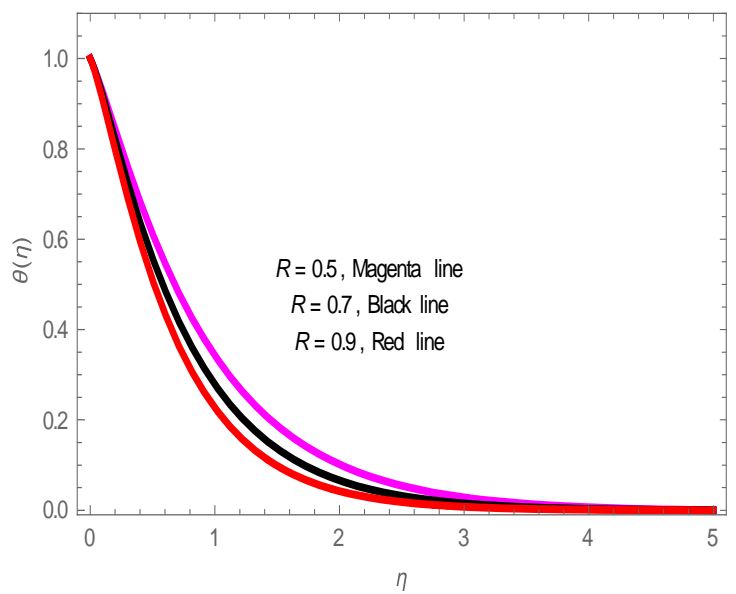

(b) $(\mathrm{Au}-\mathrm{Cu}) /$ Ethylene hybrid nanofluids.

Figure 11. $\theta(\eta)$ for dissimilar values of $R$.

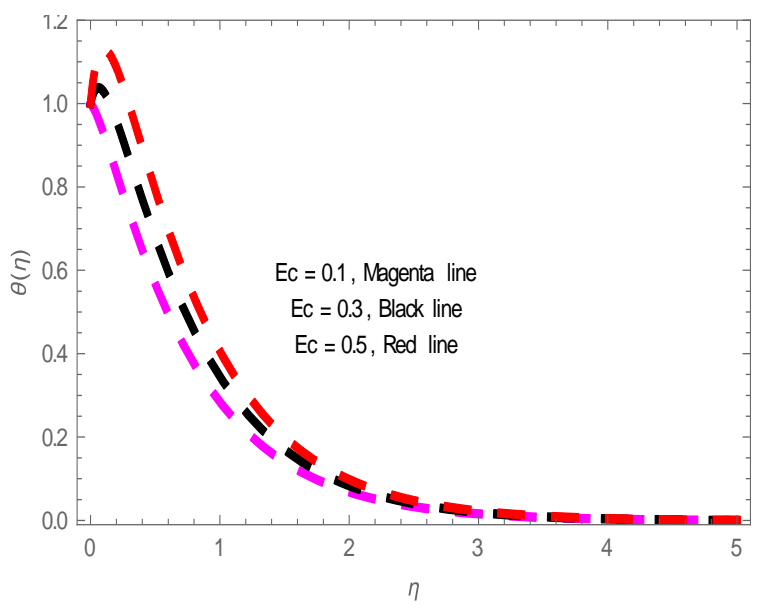

(a) (Au-Cu)/Water hybrid nanofluids.

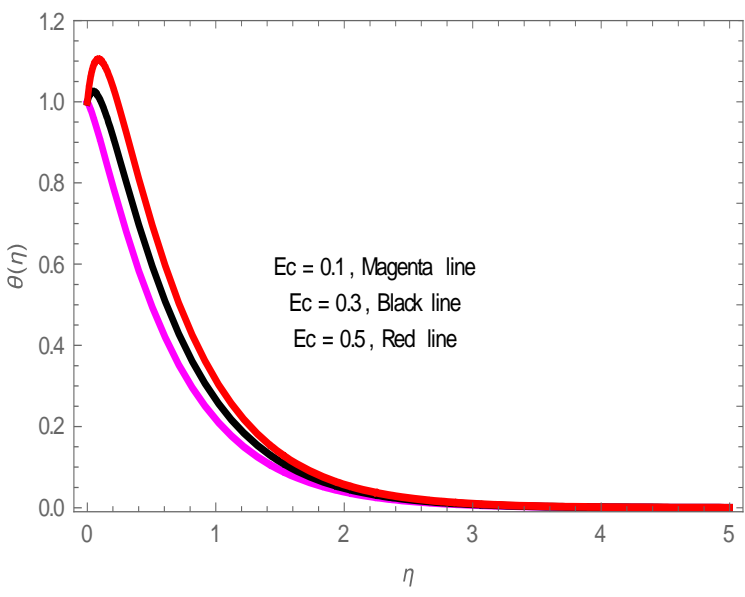

(b) $(\mathrm{Au}-\mathrm{Cu}) /$ Ethylene hybrid nanofluids.

Figure 12. $\theta(\eta)$ for dissimilar values of Ec.

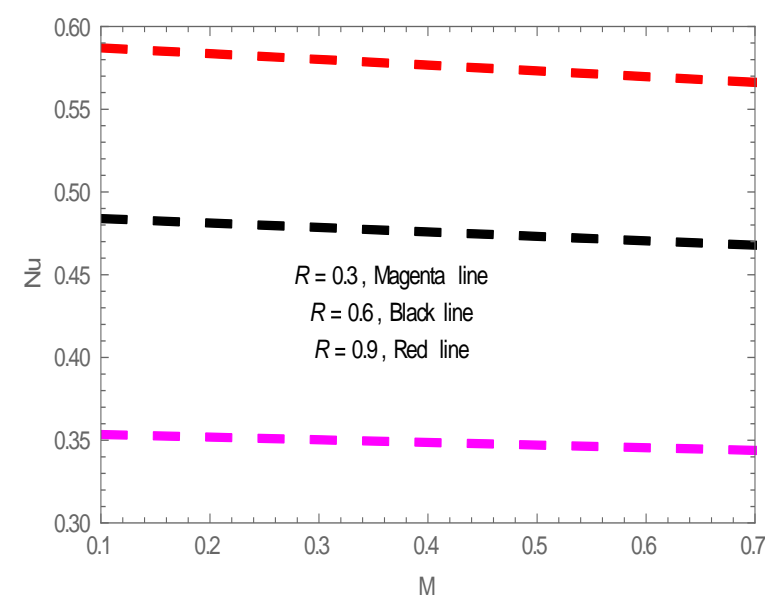

(a) (Au-Cu)/Water hybrid nanofluids.

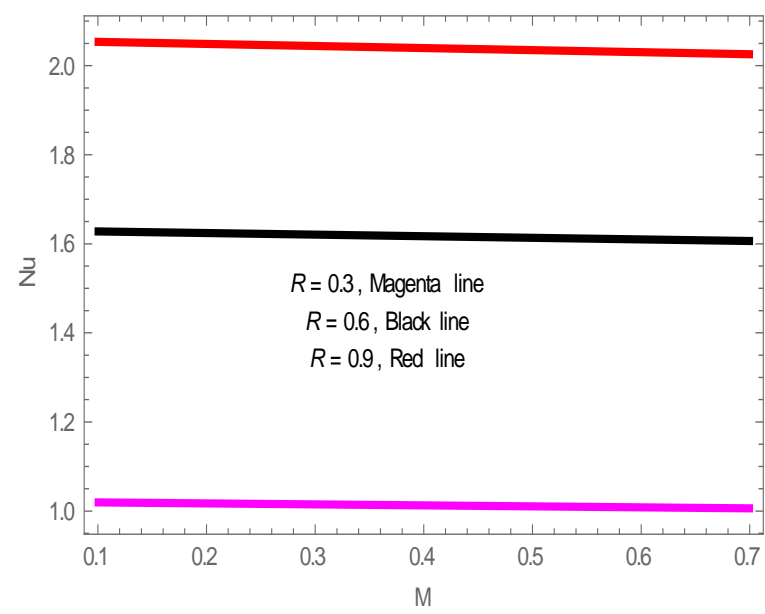

(b) (Au-Cu)/Ethylene hybrid nanofluids.

Figure 13. $\mathrm{Nu}$ for dissimilar values of $R$. 


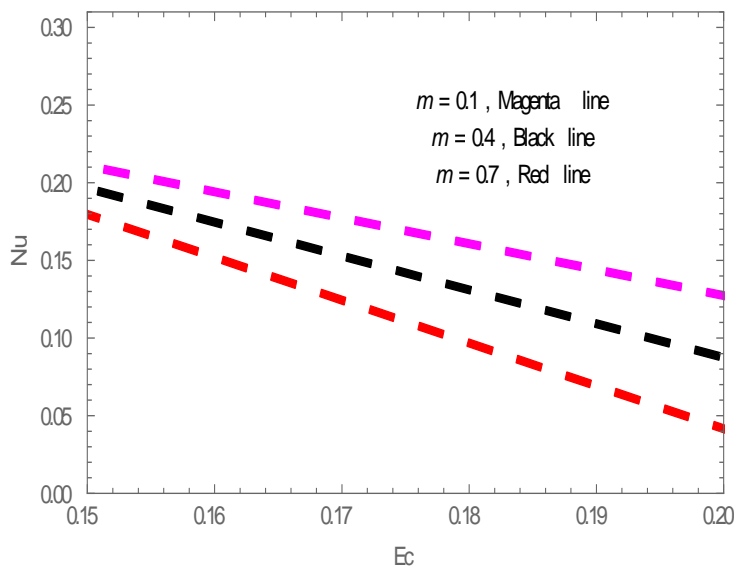

(a) (Au-Cu)/Water hybrid nanofluids.

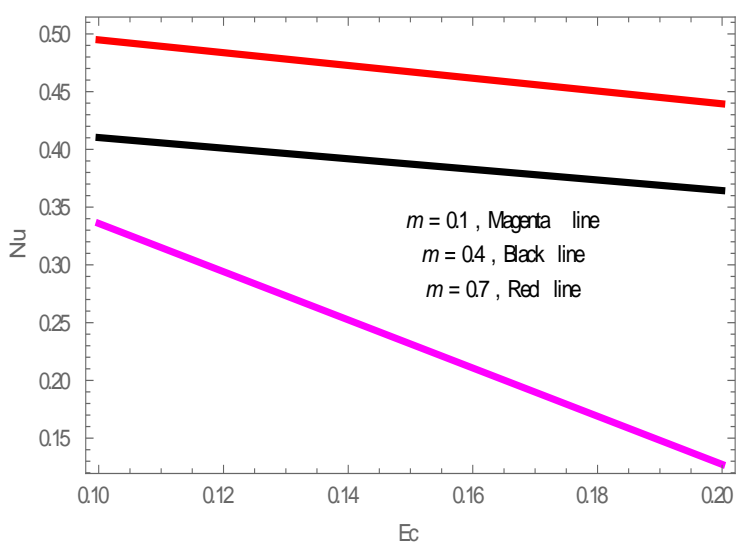

(b) $(\mathrm{Au}-\mathrm{Cu}) /$ Ethylene hybrid nanofluids.

Figure 14. $\mathrm{Nu}$ for dissimilar values of $R$.

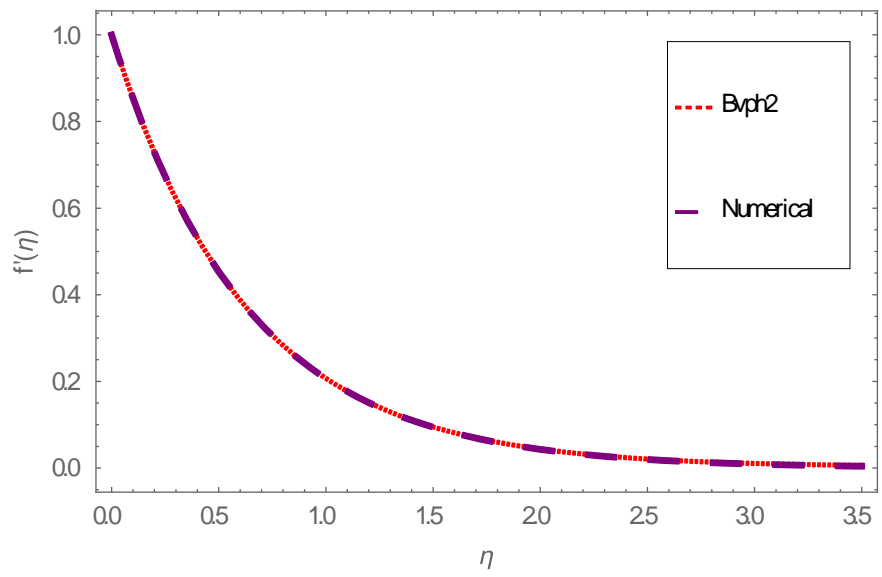

Figure 15. Velocity comparison.

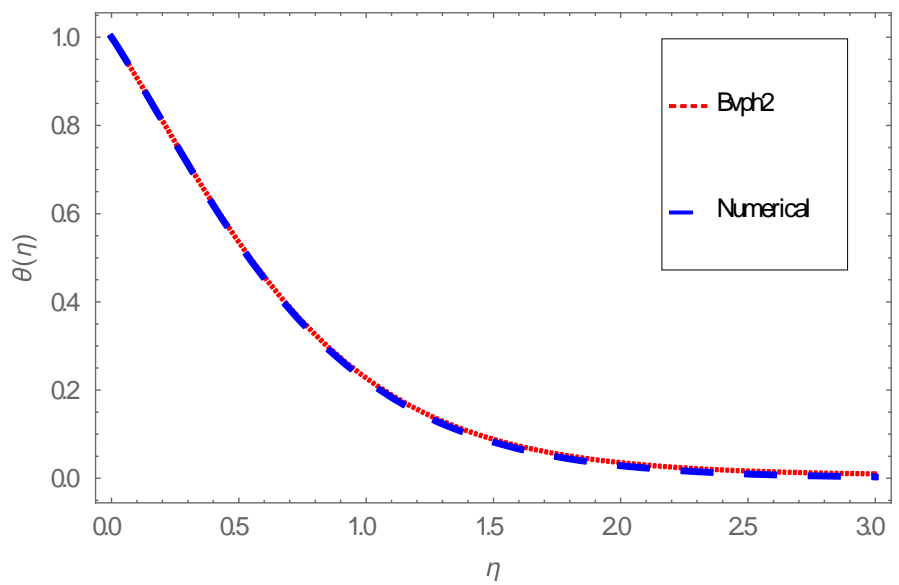

Figure 16. Temperature comparison. 


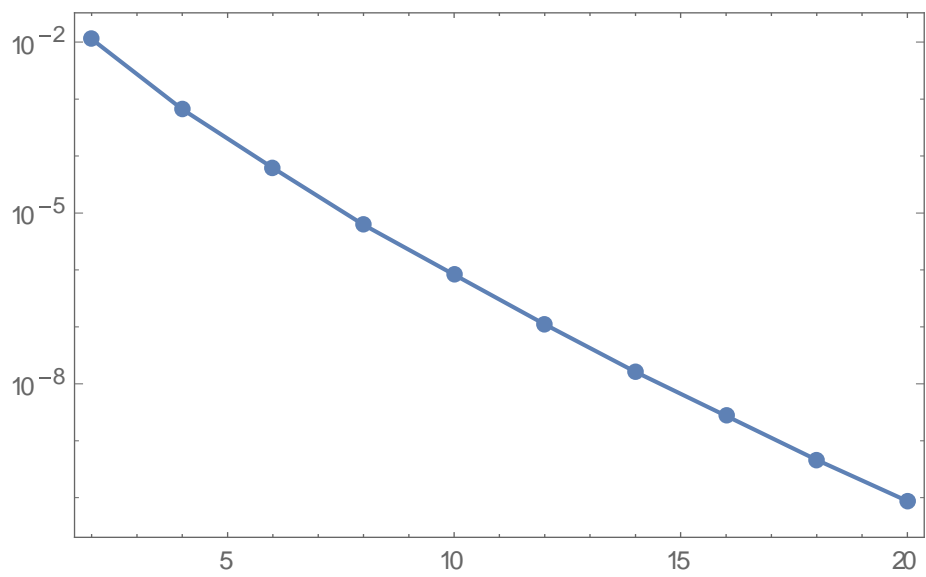

Figure 17. Error decay for the 10th-order approximation.

Table 2. Comparison of (Au-Cu)/Ethylene hybrid nanofluid velocity.

\begin{tabular}{cccc}
\hline $\boldsymbol{\eta}$ & HAM Solution & Numerical Solution & Absolute Error \\
\hline 0.0 & 1.000000 & 1.000000 & $2.220450 \times 10^{-16}$ \\
0.5 & 0.453236 & 0.453169 & 0.000067 \\
1.0 & 0.206552 & 0.206391 & 0.000162 \\
1.5 & 0.094515 & 0.094212 & 0.000303 \\
2.0 & 0.043547 & 0.043037 & 0.000510 \\
2.5 & 0.020462 & 0.019646 & 0.000816 \\
3.0 & 0.010201 & 0.008933 & 0.001268 \\
3.5 & 0.005947 & 0.004007 & 0.001941 \\
4.0 & 0.004661 & 0.001712 & 0.002948 \\
4.5 & 0.005063 & 0.000601 & 0.004461 \\
5.0 & 0.006738 & $6.174460 \times 10^{-8}$ & 0.006738 \\
\hline
\end{tabular}

Table 3. Comparison of (Au-Cu)/Ethylene hybrid nanofluid temperature.

\begin{tabular}{cccc}
\hline$\eta$ & HAM Solution & Numerical Solution & Absolute Error \\
\hline 0.0 & $-2.246840 \times 10^{-17}$ & 0.000000 & $2.246840 \times 10^{-17}$ \\
0.5 & 0.345258 & 0.345242 & 0.000016 \\
1.0 & 0.502156 & 0.502084 & 0.000072 \\
1.5 & 0.573783 & 0.573598 & 0.000185 \\
2.0 & 0.606641 & 0.606256 & 0.000385 \\
2.5 & 0.621884 & 0.621172 & 0.000712 \\
3.0 & 0.629198 & 0.627972 & 0.001225 \\
3.5 & 0.633067 & 0.631050 & 0.002016 \\
4.0 & 0.635631 & 0.632409 & 0.003222 \\
4.5 & 0.638004 & 0.632956 & 0.005048 \\
5.0 & 0.640903 & 0.633094 & 0.007810 \\
\hline
\end{tabular}

Table 4. Comparison of present results with published results for $m=0, E c=0, M=0, \phi_{1}, \phi_{2}=0$.

\begin{tabular}{ccccc}
\hline $\boldsymbol{P r}$ & Chen [32] & Zaimi et al. [33] & Naramgari and Sulochana [34] & Present Results \\
\hline 0.72 & 0.46315 & 0.463145 & 0.463146 & 0.46325153 \\
1 & 0.58199 & 0.581977 & 0.581979 & 0.58198148 \\
3 & 1.16523 & 1.165246 & 1.165249 & 1.16524542 \\
7 & 1.89537 & 1.895403 & 1.895406 & 1.895402875 \\
10 & 2.30796 & 2.308004 & 2.30808 & 2.308003593 \\
\hline
\end{tabular}

\section{Conclusions}

This study investigates the effects of viscous dissipation and ohmic heating on the flow of $(\mathrm{Au}-\mathrm{Cu}) /$ Water and $(\mathrm{Au}-\mathrm{Cu}) /$ Ethylene glycol hybrid nanofluids through a linear 
stretching porous plate. A well-known Mathematica software, NDSolve, is used to solve the nonlinear differential equations numerically. The numerical results are compared with the analytical results via the homotopy analysis method and excellent agreement is noted. The study revealed impacts of relevant physical parameters, i.e., radiation parameter, Prandtl number, injection parameter, Eckert number, and magnetic parameter on hybrid nanofluids flow and the characteristics of heat transfer. It is pointed out that the velocity of $(\mathrm{Au}-\mathrm{Cu}) /$ Water and $(\mathrm{Au}-\mathrm{Cu}) /$ Ethylene glycol hybrid nanofluids are decreased with increasing the value of $m, M, R$ and velocity is increased with the impact of $K$. The temperature of $(\mathrm{Au}-\mathrm{Cu}) /$ Water and $(\mathrm{Au}-\mathrm{Cu}) /$ Ethylene glycol hybrid nanofluids decreased with the influences of $\phi_{1}=\phi_{2}, R$ and $m$, while the temperature of $(\mathrm{Au}-\mathrm{Cu}) /$ water and $(\mathrm{Au}-\mathrm{Cu}) /$ Ethylene glycol hybrid nanofluids is increased with the effects of $E c$ and $M$. The heat transfer rate of $(\mathrm{Au}-\mathrm{Cu}) /$ Ethylene glycol hybrid nanofluid is also greater when compared to the $(\mathrm{Au}-\mathrm{Cu}) /$ Water hybrid nanofluid.

Author Contributions: Conceptualization, U.R., A.I. and A.A.; methodology, U.R. and A.I.; software, U.R. and A.I; validation, U.R., A.I. and A.A.; formal analysis, U.R. and A.I.; investigation, U.R., A.I. and A.A.; resources, A.I. and A.A.; data curation, U.R. and A.A.; writing-original draft preparation, U.R. and A.I.; writing—review and editing, U.R., A.I. and A.A.; visualization, U.R., A.I. and A.A. All authors have read and agreed to the published version of the manuscript.

Funding: This research received no external funding.

Acknowledgments: The authors would like to thank Taif University Researches Supporting Project (TURSP-2020/96), Taif University, Taif, Saudi Arabia, for their financial assistance. The authors also wish to express their gratitude to anonymous referees for their excellent comments and recommendations, which substantially improved the work.

Conflicts of Interest: The authors declare no conflict of interest.

\section{Nomenclature}

$T \quad$ Temperature of nanofluid (k)

$u, v \quad$ The velocity components $(\mathrm{m} / \mathrm{s})$

$k_{n_{f}} \quad$ Thermal conductivity of the nanofluid (W/m K)

$k_{f} \quad$ Thermal conductivity of the fluid $(\mathrm{W} / \mathrm{m} \mathrm{K})$

$k_{s} \quad$ Thermal conductivity of the solid $(\mathrm{W} / \mathrm{m} \mathrm{K})$

Cp Specific heat capacity (J/kg K)

$\alpha_{n_{f}} \quad$ Thermal diffusivity of the nanofluid $\left(\mathrm{m} / \mathrm{s}^{2}\right)$

$\rho_{n_{f}} \quad$ Density of the nanofluid $\left(\mathrm{kg} / \mathrm{m}^{3}\right)$

$\rho_{f} \quad$ Density of the fluid $\left(\mathrm{kg} / \mathrm{m}^{3}\right)$

$\rho_{s} \quad$ Density of the solid $\left(\mathrm{kg} / \mathrm{m}^{3}\right)$

$\phi \quad$ Solid volume fraction

$\mu_{n_{f}} \quad$ Dynamic viscosity of the nanofluid $\left(\mathrm{N} \cdot \mathrm{sm}^{-2}\right)$

$\mu_{f} \quad$ Dynamic viscosity of the fluid $\left(\mathrm{N} \cdot \mathrm{sm}^{-2}\right)$

$\mu_{s} \quad$ Dynamic viscosity of the solid $\left(\mathrm{N} \cdot \mathrm{sm}^{-2}\right)$

$\sigma^{*} \quad$ Stefan-Boltzmann constant $\left(\mathrm{w} \cdot \mathrm{m}^{-2} \cdot \mathrm{k}^{-4}\right)$

$k^{*} \quad$ Absorption coefficient $\left(\mathrm{m}^{-1}\right)$

$R \quad$ Radiation parameter

$m \quad$ Injection parameter

$k \quad$ Porous medium

Pr Prandtl number

Ec Eckert number

M Magnetic parameter

$\sigma \quad$ Electrical conductivity

$q_{r} \quad$ Radiative heat flux

$h n_{f}$ Hybrid Nanofluid

$S \quad$ Solid

$f \quad$ Liquid 


\section{References}

1. Hayat, T.; Haider, F.; Muhammad, T.; Alsaedi, A. Numerical study for Darcy-Forchheimer flow of nanofluid due to an exponentially stretching curved surface. Results Phys. 2018, 8, 764-771. [CrossRef]

2. Ullah, I.; Rahim, M.T.; Khan, H.; Qayyum, M. Analytic Comparison of MHD Squeezing Flow in Porous Medium with Slip Condition. Phys. Res. Int. 2016, 2016, 5407916. [CrossRef]

3. Ahmad, S.; Khan, M.I.; Hayat, T.; Khan, M.I.; Alsaedi, A. Entropy generation optimization and unsteady squeezing flow of viscous fluid with five different shapes of nanoparticles. Colloids Surf. A Physicochem. Eng. Asp. 2018, 554, 197-210. [CrossRef]

4. Qayyum, S.; Khan, M.I.; Chammam, W.; Khan, W.A.; Ali, Z.; Ul-Haq, W. Modeling and theoretical investigation of curved parabolized surface of second-order velocity slip flow: Combined analysis of entropy generation and activation energy. Mod. Phys. Lett. B 2020, 34, 1-15. [CrossRef]

5. Li, Y.M.; Khan, M.I.; Khan, S.A.; Khan, S.U.; Shah, Z. An assessment of the mathematical model for estimating of entropy optimized viscous fluid flow towards a rotating cone surface. Sci. Rep. 2021, 11, 1-15. [CrossRef]

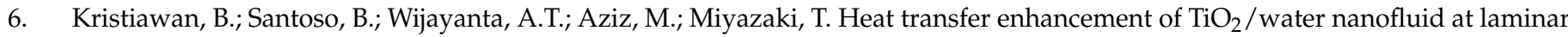
and turbulent flows: A numerical approach for evaluating the effect of nanoparticle loadings. Energies 2018, 11, 1584. [CrossRef]

7. Kristiawan, B.; Rifa'i, A.I.; Enoki, K.; Wijayanta, A.T.; Miyazaki, T. Enhancing the thermal performance of TiO2/water nanofluids flowing in a helical microfin tube. Powder Technol. 2020, 376, 254-262. [CrossRef]

8. Choi, S.U.S.; Eastman, A. Enhancing thermal conductivity of fluids with nanoparticles. In Proceedings of the 1995 International Mechanical Engineering Congress and Exhibition, San Francisco, CA, USA, 12-17 November 1995; Volume 66, pp. 99-105.

9. Aprea, C.; Greco, A.; Maiorino, A. Enhancing the Heat Transfer in an Active Barocaloric Cooling System Using Ethylene-Glycol Based Nanofluids as Secondary Medium. Energ. Artic. 2019, 12, 2902. [CrossRef]

10. Devi, S.P.A.; Devi, S.S.U. Numerical Investigation of Hydromagnetic Hybrid $\mathrm{Cu}-\mathrm{Al}_{2} \mathrm{O}_{3} /$ Water Nanofluid Flow over a Permeable Stretching Sheet with Suction. J. Int. J. Nonlinear Sci. Numer. Simul. 2016, 17, 249-257. [CrossRef]

11. Hayat, T.; Nadeem, S. Heat transfer enhancement with Ag-CuO/water hybrid nanofluid. Results Phys. 2017, 7, 2317-2324. [CrossRef]

12. Anuar, N.S.; Bachok, N.; Pop, I. Cu- $\mathrm{Al}_{2} \mathrm{O}_{3}$ /water hybrid nanofluid stagnation point flow past MHD stretching/shrinking sheet in presence of homogeneous-heterogeneous and convective boundary conditions. Mathematics 2020, 8, 1237. [CrossRef]

13. Khashi'ie, N.S.; Arifin, N.M.; Pop, I.; Wahid, N.S. Flow and heat transfer of hybrid nanofluid over a permeable shrinking cylinder with Joule heating: A comparative analysis. Alex. Eng. J. 2020, 59, 1787-1798. [CrossRef]

14. Khan, A.; Saeed, A.; Tassaddiq, A.; Gul, T.; Majmaah, I.S.; Technology, I. Bio-convective and Chemically Reactive Hybrid Nanofluid Flow upon a Thin Stirring Needle with Viscous Dissipation. Sci. Rep. 2011, 11, 1-29. [CrossRef]

15. Santhi, M.; Suryanarayana Rao, K.V.; Sudarsana Reddy, P.; Sreedevi, P. Heat and mass transfer characteristics of radiative hybrid nanofluid flow over a stretching sheet with chemical reaction. Heat Transf. 2020, 7, 9-12. [CrossRef]

16. Al-mdallal, Q.M.; Indumathi, N.; Ganga, B.; Hakeem, A.K.A. Marangoni radiative effects of hybrid-nanofluids flow past a permeable surface with inclined magnetic field. Case Stud. Therm. Eng. 2020, 17, 100571. [CrossRef]

17. Waini, I.; Ishak, A.; Pop, I. Hybrid nanofluid flow towards a stagnation point on a stretching/shrinking cylinder. Sci. Rep. 2020, 10, 1-12. [CrossRef]

18. Zainal, N.A.; Nazar, R.; Naganthran, K.; Pop, I. Stability analysis of MHD hybrid nanofluid flow over a stretching/shrinking sheet with quadratic velocity. Alex. Eng. J. 2021, 60, 915-926. [CrossRef]

19. Babazadeh, H.; Shah, Z.; Ullah, I.; Kumam, P.; Shafee, A. Analysis of hybrid nanofluid behavior within a porous cavity including Lorentz forces and radiation impacts. J. Therm. Anal. Calorim. 2020, 143, 1129-1137. [CrossRef]

20. Khanafer, K.; Vafai, K. Applications of nanofluids in porous medium: A critical review. J. Therm. Anal. Calorim. 2019, 135, 1479-1492. [CrossRef]

21. Mohyud-Din, S.T.; Ahmed, N.; Khan, U. Flow of a radioactive Casson fluid through a deformable asymmetric porous channel. Int. J. Numer. Methods Heat Fluid Flow 2017, 27, 2115-2130. [CrossRef]

22. Sheikholeslami, M.; Ellahi, R.; Shafee, A.; Li, Z. Numerical investigation for second law analysis of ferrofluid inside a porous semi annulus: An application of entropy generation and exergy loss. Int. J. Numer. Methods Heat Fluid Flow 2019, 29, 1079-1102. [CrossRef]

23. Masood, S.; Farooq, M.; Ahmad, S.; Anjum, A.; Mir, N.A. Investigation of viscous dissipation in the nanofluid flow with a Forchheimer porous medium. Eur. Phys. J. Plus Vol. 2019, 134, 178. [CrossRef]

24. Alaidrous, A.A.; Eid, M.R. 3-D electromagnetic radiative non-Newtonian nanofluid flow with Joule heating and higher - order reactions in porous materials. Sci. Rep. 2020, 10, 1-19. [CrossRef]

25. Zubair Akbar, M.; Ashraf, M.; Farooq Iqbal, M.; Ali, K. Heat and mass transfer analysis of unsteady MHD nanofluid flow through a channel with moving porous walls and medium. AIP Adv. 2016, 6, 045222. [CrossRef]

26. Mishra, S.R.; Mathur, P. Williamson nanofluid flow through porous medium in the presence of melting heat transfer boundary condition: Semi-analytical approach. Multidiscip. Model. Mater. Struct. 2020, 17, 19-33. [CrossRef]

27. Uddin, M.J.; Khan, W.A.; Ismail, A.M. Free convective flow of non-newtonian nanofluids in porous media with gyrotactic microorganism. J. Thermophys. Heat Transf. 2013, 27, 326-333. [CrossRef]

28. Lund, L.A.; Omar, Z.; Dero, S.; Khan, I.; Baleanu, D.; Nisar, K.S. Magnetized Flow of $\mathrm{Cu}+\mathrm{Al}_{2} \mathrm{O}_{3}+\mathrm{H}_{2} \mathrm{O}$ Hybrid Nanofluid in Porous Medium: Analysis of Duality and Stability. Symmetry 2020, 12, 1513. [CrossRef] 
29. Ting, T.W.; Hung, Y.M.; Osman, M.S.; Yek, P.N. Heat and Flow Characteristics of Nanofluid Flow in Porous Microchannels. Int. J. Automot. Mech. Eng. 2018, 15, 5238-5250. [CrossRef]

30. Bég, O.A.; Prasad, V.R.; Vasu, B. Numerical study of mixed bioconvection in porous media saturated with nanofluid containing oxytactic microorganisms. J. Mech. Med. Biol. 2013, 13, 1350067. [CrossRef]

31. Kumar, H. Homotopy perturbtion method analysis to MHD flow of a radiative nanofluid with viscous dissipation and ohmic heating over a stretching porous plate. Therm. Sci. 2018, 22, 413-422. [CrossRef]

32. Chen, C.H. Laminar mixed convection adjacent to vertical, continuously stretching sheets. Heat Mass Transf. Stoffuebertragung 1998, 33, 471-476. [CrossRef]

33. Yacob, N.A.; Ishak, A. Stagnation-point flow over a nonlinearly stretching/shrinking sheet in a micropolar fluid. AIP Conf. Proc. 2014, 1602, 266-272. [CrossRef]

34. Naramgari, S.; Sulochana, C. MHD flow over a permeable stretching/shrinking sheet of a nanofluid with suction/injection. Alex. Eng. J. 2016, 55, 819-827. [CrossRef] 